\title{
Auditor Independence and Mandatory Auditor Rotation in Jordan
}

\author{
Abeer Fayez Al-Khoury ${ }^{1}$, Ala'eddin Ali $^{1}$, Mahmoud Al-Sharif $^{1}$, Jabra Hanania $^{1}$, Iyad Al-Malki ${ }^{1}$ \& \\ Mohammad Jallad ${ }^{1}$ \\ ${ }^{1}$ Princess Sumaya University for Technology, Jordan \\ Correspondence: Abeer Fayez Al-Khoury, Princess Sumaya University for Technology, Jordan. Tel: \\ 962-795-200-117. E-mail: a.khoury@psut.edu.jo \\ Received: November 19, 2014 \\ Accepted: March 4, 2015 \\ Online Published: March 25, 2015 \\ doi:10.5539/ibr.v8n4p73 \\ URL: http://dx.doi.org/10.5539/ibr.v8n4p73
}

\begin{abstract}
Purpose: The purpose of this study is to test the relationship between auditor rotation and the level of auditor independency, and to investigate, the impact of auditor rotation, audit fees, audit tenure and the relationship with client on the auditor independency in Jordanian audit firms. Furthermore, to identify the reasons behind rotating the auditor and the advantages/disadvantages of auditor rotation.
\end{abstract}

Design/methodology/approach: The study has been carried out through a questionnaire survey that aimed to collect data about the auditor independency in Jordan, and through a developed model to test the mandatory auditor rotation in the Jordanian audit firms.

Findings: After defining the four independent main variables of the auditor independency (auditor-client relationship, audit tenure, audit fees, and mandatory auditor rotation). The findings of the study revealed that there is a significant positive relationship between the auditor independency and auditor-client relationship and mandatory rotation. A negative one with the audit fees and there is no relationship with audit tenure.

Research limitations/implications: This paper has some limitations such as, some audit firms refused to allow researchers to distribute the questionnaire which is not familiar in Jordan.

Originality Value: This paper contributes to the understandings of the nature and characteristics of the auditor independency by empirically exploring the nature and characteristics of mandatory auditor rotation in Jordan.

Keywords: auditor independence, mandatory audit rotation, audit fees, audit tenure, auditor-client relationship

\section{Introduction}

Prospective investors are a very important part of users as they need to assess the viability of investing in a specific company; they are looking to maximize their wealth through investing in profitable companies. Investors may try to predict dividends or the chance of maximizing their shares value based on audited financial statements, risks related with investment may be measured from the financial statements, for example, fluctuating profits indicates a very high risk.

The main and the most important objective of financial statements is providing useful information about the financial position of the company that can be used by a wide range of users in making decisions; it provides useful information to a very huge and wide range of potential users such as: Shareholders who use the financial statements to decrease the risk and assess the return of their investment in a specific company as they also use it to take important investment decisions based on their own analysis. In conclusion, Financial Statements provide the backbone for the investment decisions of potential investors.

Due to the increasing importance of financial statements, users always seek high quality and fairly presented financial statements, people need to have trust in these statements, in order to reach this trusted and well prepared statements the auditors role is located in the spot light in front of the public because they are highly educated professionals who express their opinion on the financial statements and decide whether it is an unqualified or a qualified audit report.

The importance of external auditing is to assure that financial statements are accurate and free from misstatements. When these audited statements published with free or little misstatements the auditor grant credibility and positive reputation to the clients company, external auditing is more credible than internal auditing (Jack Ori, 2009). 
The audit profession has reached a high level in many countries such as USA, England and Germany due to auditors' high independency and a lot of other rules and factors.

In most situations, public needs to have authenticity in financial statements and auditors who are auditing these financial statements. In order to reach a high authenticity, auditors must be independent. There are a lot of factors that affect auditor's independency such as auditor's rotation which can enhance the auditor independency and prevent the creation of a relationship between the auditor and the client firm.

Auditor independence is considered to be the main cornerstone in the auditing profession and practices. In most cases, auditor independency consists of two general forms: "independence in fact" and "independence in appearance". Former requires auditors to form and express an opinion in the audit report as a dispassionate and expert observer, not influenced by personal bias, while the latter expects auditors to avoid situations and circumstances that might cause others to deduce that they are not maintaining an unbiased objective behavior of mind (Porter et al., 2003).

The auditor independence may negatively affected or lost if the auditor gains a personal relationship with the client as this may affect their ability to conduct an unbiased opinion. One of the threats that could lead to the lack of auditor opinion auditor-client relationships is having the same auditor for a long period of time (Flint, 1988). Flint (1988) also contends that having the same auditor for a long period of time in the office may result in an "over cozy-relationships", they might also develop some kind of loyalty for their clients, which will eventually lead to threatening the auditor's independency. Having the same auditor for a long period of time will also cause "Over familiarity" and the auditor will start making unjustified assumptions instead of unbiased evaluation of evidence (Flint, 1988).

Apart from the audit rotation, when the auditor's tenure increases, so will the auditor understands the client's business, control risks and other factors that result to the failure of the audit profession (AICPA, 1992). Given the controversies on auditor tenure Congress in 2002, decided not to require the mandatory rotation of audit firms. Instead, it directed the General Accounting Office (GAO) Conduct research on the potential effects of mandatory audit firm rotation on audit quality. The GAO's (2003) study of the largest public accounting firms and their Fortune 1000 publicly traded client-companies concluded that mandatory audit firm rotation may not be the most efficient way to strengthen auditor independence and improve audit quality.

The audit quality has always been considered one of the most important topics in the audit profession. If the auditor is able to detect the existing material misstatements and report them, the audit report would be considered of a high quality. What would effect and impair the auditor's independence and his ability to conduct an unqualified audit report is the prolonged auditor-client relationship (Vanstraelen, 2000; Hamilton et al., 2005).

Auditor independence has always been a long debated subject between both professionals and academics. High profile accounting conflicts such as Enron and WorldCom have spotted light on the continuing arguments about whether and how auditors can be independent. The proposed solution for the prolonged auditor-client relationship and the lack of auditor independency is the mandatory audit rotation. The mandatory audit rotation forces each listed company to change its audit firm or at least its audit partner after a certain period of time (Arel et al., 2005). Rotating the auditor is very important and required by law in many countries for two main reasons: First to preserve the auditor independence that would be negatively affected by the intimacy of the auditor-client personal relationships. Second to improve the audit quality by encouraging the creativity in auditing approaches and methods that might be bounded by the intimacy of the auditor-client relationship (Carey \& Simnett, 2006).

In this study, we are trying to find the possible effects of mandatory audit firm rotation on auditor independence and the quality of audit reports. Mandatory audit firm rotation has been recommended for a long time to improve the quality of the audit reports and maintain the auditor independency. For example, the Report of the Commission on Auditors' Responsibilities (Cohen Commission, 1978) suggests that mandatory rotation might change auditor incentives and bring a "fresh viewpoint" to audit engagements.

There is a positive effect on auditor's independence when applying audit rotation and it could be mandatory or voluntary. The mandatory audit rotation means that the auditors of the firm must be changed after a certain period of time while the auditor rotation in the firm is optional in the voluntary audit rotation.

The current study is expected to contribute to the literature on the determinants of audit rotation by providing empirical evidence on the impact of audit rotation on audit independency in an emerging economy; Jordan, as well as knowing the extent of audit rotation. This may assist in improving the current audit rotation requirements. Similarly, understanding the impact of audit rotation on audit independency may assist policy-makers in revising the items (general guidelines and requirements). 


\section{Theoretical Background}

The main purpose of the financial statements is to present a brief overview about the economic and financial position of the entity, these statements used by the company's management, government, labor union and other stakeholder for decision making process.

Financial statements should be reliable and fair to reflect the actual financial position of the company to enable the users to take the most appropriate decisions and attain the corporate objectives. Through auditing the auditors are going to assess the risk of errors and misstatements during the year to ensure that the financial statements are fairly presented and to evaluate the performance and internal control system of the company (Clements, 2011). The auditor reputation plays an effective role in assure the truthfulness of financial statements, many factors incorporated to build this reputation. The most important factor is the auditor's independence (Simunic, 1984).

Auditor independence is the most important features in audit profession. Lack of auditor independence may cause injustice, problem between the audit firm and the client; in some cases it may cause bankruptcy of business and damage it as Enron and WorldCom scandal which considered the largest bankruptcy reorganization in American history (Khan, 2002). When the auditor is regarded being independence, the financial information are more confidential for the public and used to make right decisions (Ghoshand Moon, 2004).

To increase independency auditors must follow and implement two aspects: first to be independent and objective as individual (Practitioner's Independence), second the apparent independence of the auditor as a professional group to the society (Professional independence) (Izedonmi, 2000), The auditor should be independent on both of these aspects to provide a high level of professionalism on his work. Long auditor tenure is a major issue that effect negatively on audit independence, as the long relationship between the auditor and the client may lead to deterioration on the quality of the audit report (Mautz \& Sharaf, 1961). The objectivity of the Auditor's opinion and his judgment on his client decreases over time due to the extended relationship between them. The personal and long-relationship between auditor and client tend the auditor to issue a qualified audit report.

Independency of auditors may increased through implementing the mandatory audit rotation in order to improve transparency between auditing committees and investors, mandatory audit rotation should reduce the risk of collusion and enhance the audit quality over the years (Hoyle, 1978).

\subsection{Audit Rotation}

McKesson Robbins accounting scandal of the 1930s was the shock which push the investor to reevaluate the confidence and validity of financial statement, although Price Waterhouse failed to detect $\$ 19$ million in misstatements of inventory and receivables, McKesson Robbins falsified records, and Price Waterhouse did not question or verify the validity of their financial statements. This fraud was followed by congressional hearings and attempts to reform the auditing and accounting profession, which was the reason to develop the first formal standards for auditing procedures and the beginning of mandatory audit rotation as a technique to improve audit quality (Ramos, 2002).

The issue tends to resurface as a major audit failure of a corporation collapses (Catanach \& Walker, 1999).

Enron and WorldCom companies audit failure caused doubts in audits and the accounting profession in general and demanded much scrutiny; thus, 233 companies had to correct misstatements and earnings which raged the public for changes in regulations (Kahn, 2002).

Auditor rotation is motivated by public as a one of important tools to improve and increase the audit quality and the validity of financial statement corporate, which is recommended to be five to seven years then the firm change the audit firm, the main purpose of it is to limit the client-auditor relationships, in which the auditor loyalties may become divided, and thus reduce the auditor's independence one successful example was DuPont Company which used mandatory rotation from 1910 to 1954.

In the absence of audit rotation the auditor may using the same approach and audit program for several years, audit will lack the creativity it had in the beginning of the time that it will become predictable and ineffective (Hoyle, 1978). Audit rotation shall helps to get a fresh perspective on the client's financial statements and the new audit firm might be able to detect things in statements that the previous firm couldn't overlook and errors of the previous firm (McLaren, 1958). It also gives the opportunity to scrutinize other firm's work instead of just applying the peer review program (Catanach et al., 1999). This motivates audit firms to do their best in order to avoid embarrassment knowing some experts are to judge their work and competition, and differentiate themselves through trying to attract new clients. However, there are some professionals who oppose audit rotation for many reasons. 


\subsection{Audit Tenure}

After very high-level audit failures such as Enron and WorldCom, the long audit tenure and its effect on audit quality has become a very important topic of public controversy in the USA. Since 1999 the US Securities and Exchange Commission (SEC) started to express its worry about the effects of the lengthy audit tenure on the auditor independence and audit quality (Accounting Today, 2004). Academics were called by the Chief Accountant of the SEC Lynn Turner to investigate whether the financial reporting quality deteriorated by the long-lasting relationship that has been developed by the client mangers and their auditors (Turner, 1999). Arthur Levitt, The Chairman of the SEC in 2000, repeated the worry of his Chief Accountant that the Judgment of the auditors was weakened by the length of the engagement with their clients (Levitt, 2000). In 2002 Levitt testified for the Senate Committee on Governmental Affairs that : Serious moves must be taken to make the companies change their audit firms not only partners every 5-7 years to make sure that fresh and new eyes are always looking at the numbers (Levitt, 2002).

Many published Studies in the USA have studied the effect of audit firm tenure on audit quality (Myers et al., 2003). Generally they came up with a conclusion supportive of the GAO's conclusions that conclude as the tenure increases, so will the audit quality. And they show that most of the mistakes in the audit reports are most likely to happen in the first few years of the tenure of a new audit firm. However, there were a few studies that have studied and examined whether the audit partner rotation also has a negative effect on audit quality. Audit firm rotation and audit partner rotation can increase the risk of audit failures and mistakes during the first few years of the auditor tenure if the rotation makes it very difficult for the new partner to learn about the client's operations (Cameran et al., 2005).

\subsection{Auditor-Client Relationship}

The relationship between the auditor and the audited is limited to either financial; such as the payment of audit fees, or personal interactions; such as and the provision of non-audit services. The American institute of certified public accountants' (AICPA) Special Committee on Assurance Services has identified several new assurance services such as risk assessment, business performance management, information systems reliability, electronic commerce, and health care performance measurement. These services aim to increase the efficiency and effectiveness of the audit, as it provides a wider awareness with the client's systems and strategies, hence offer firms substantial revenue opportunities (Elliott \& Pallais, 1997; Telborg, 1996). Auditor's main concern is to question the reasonableness of financial statement assertions made by the client, maintaining judicial impartiality (AICPA, 1992). This can be highly affected by integrity and independence; which in turn is affected by many factors such as the audit lengthy tenure, which may decrease the intensity of scrutiny and the readiness to apply professional scepticism (Mautz, 1961), and the far that the relationship can get before a mutuality of interests is created (Sutton, 1993).

\subsection{Audit Fees}

Auditors' independence is an important factor in the audit profession, therefore a lack of this independence will lead the auditor to take wrong decisions, and even more it may cause bigger problems such as business damages and bankruptcy (Ghosh, 2004). The financial statements will gain confidentiality and accuracy in the public eye when the auditor is independence (Cameran et al., 2005). Audit fees have a significant effect on the loyalty of auditor to his client, whether the client paying more or less than audit fees being paid to similar competitors. The client has the right to switch audit firms whenever there is dissatisfaction with the services provided by the auditor. (Carcello \& Neal, 2003) findings show that high audit fees lead to high auditor dismissal, in other words it leads to auditor switching. (Ettredge et al., 2007) results show that when the client is paying lower audit fees comparable with other companies in the industry more likely to be loyal to their audit firms, on the other hand the audit quality can be clearly affected by the fees paid to the auditor, financial satisfaction that obtained by high audit fees paid to auditors may increase the professionalism and the effort exerted by the auditor which enhance the audit quality.

\section{Literature Review}

(Khatab, 2013) examined the effect of joint audit and auditor Rotation on the firm's value in Egypt. To gathering data he used a model of 34 companies in 14 sectors in the Egyptian stock market and the data are annual time series from 2005 to 2009. The audit rotation and the Leverage have a significance effect of the firm value. Also there is no significance effect of applying the joint auditing on increasing the value of a firm. Also there is a significance effect of applying the auditing rotation on increasing the value of a firm. The statistical analysis showed that the factor companies have a significance effect of the value a firm, while the time has no significance effect on the dependent variable. This means that the value of a firm can differ from company to 
another. At the end of this analysis it is recommended to apply audit rotation to increase the value of a firm and increase auditor independence level.

(Harris, 2012) investigated whether mandatory rotation rules affect audit quality in sample evidence from three countries over a number of years (Italy, South Korea, and Brazil) by using an international perspective on sample evidence that includes data from 1991 to 2010. They conclude that the auditor-client relationship is going to threat the auditor's independence and increase the concern about the constant profit flow as the audit firm will consider this relationship as a long-term contract between them and the client. Another issue is due to the long auditor tenure, the auditor is going to anticipate errors and evidences because of the prior experience in the company, this threat called "familiarity threat". The auditors should collect new and innovative audit evidence.

(Fargher et al., 2008) studied the effect of audit partner tenure on client manager's accounting discretion of Australian firms that were publicly traded on the ASX over the period 1990-2004 (14 years) on a sample consist of firms from 20 industries. The purpose of the study aimed to examine the effect of audit partner tenure on client managers' accounting discretion. They used a model to analyze their hypotheses of comparing audit quality associated with short- and long-tenured audit partners with audit quality associated with medium-tenured audit partners. The authors examined that, in the initial years of tenure of a new audit partner, client managers' accounting discretion decreases when the new partner is from the same audit firm as the outgoing partner. However, when the new audit partner is from a different audit firm as the outgoing partner (audit firm rotation), it is found that client manager's accounting discretion increases in those initial year.

(Zhang et al., 2006) examined a sample of 372 companies from the united states through electronic newsletter from 2004 to 2006 to find the relationship between the audit committee, auditors independence and disclosure of control weaknesses, this study indicates that the independency of an auditor influenced by the financial bond, the auditor tends to issue unqualified audit report and ignore problems in the internal control of the clients company.

But some other studies (Francis, 2004) examined the relation between the fees paid to auditors for audit and non-audit services during the year of 2001 by using pooled sample contains 3,133 unique firms in the United States within 1 year before and 1 year after a firm's first disclosure of fees paid to auditors, the study shows that the auditor has an incentive to provide a high quality of audit work to preserve his reputation, as the client fees are a small proportion from the total income of the audit firm.

(Chung, 2004) A multivariate regression analyses are used for testing a sample consists of Canadian firms listed on the Toronto Stock Exchange from 2002 to 2004 to study the impact of the limited auditor tenure on earnings, and thus audit quality by taking advantage of the unique audit regulations that govern the listed firms in Korea, by examining how discretionary accruals, a measure of earnings quality drawn from prior literature, vary around an event that imposed a limit on the length of the auditor-client relationship via the auditor designation requirement for Korean firms likely to manage earnings. The study found that limiting the length of the auditor-client relationship will be more motivating for auditors to maintain independence as it will improve the audit quality, which will provide more incentives to resist management pressures and thus holds firms from manipulating earnings.

(Cameran et al., 2005) have studied the effect of the auditor engagement period on the quality of audit. To gather data, auditors have been appointed for a 3-year period engagement that can be renewed twice up to 9 years of engagement. Found that the auditor's conservatism increases in the last 3-year period, the last one before the mandatory rotation, as well-known (Basu, 1997) model on timely loss recognition has confirmed. They have also hired earnings response coefficients as a proxy to measure investors' perception of audit quality, which have showed audit quality perception increase in the last 3-year period.

(Myers et al., 2003) argued and provided evidences on the potential impact of the mandatory audit firm rotation on the financial reporting quality and for the purpose of getting the data the analyzed a sample of public companies that issued financial statement restatements between January 1997 and October 2001, they compared these financial statements restatements to a match of set of non-restating public companies and found that mature companies are more likely in general to have longer auditor tenure and are in most situations less likely to make restatements. And figured out that audit tenure is not significantly related to the chance and probability of restatements in the overall, to be specific misstatements that do not increase non-core earnings are less likely as the auditor-client relationship lengthens.

From another side, misstatements the increase earnings are more likely as tenure lengthens, but other examination shows that this result is related with restatements of quarterly financial statements, which are reviewed rather than audited. 
Auditor tenure is not directly related with significant increase in the propensity for restatements of annual financial reports, putting eye on just the restatements example, we discover that no evidence that changing auditors effects the likelihood that the auditor identifies the need for restatements(Myers et al., 2003).

(Davis et al., 2002) studied the relation between the length of auditor tenure and the extent of absolute discretionary accruals and forecast errors (defined as actual earnings less earnings forecasts). By sampling 855 firms over the period 1981 to 1998, the study found a positive relation between tenure and absolute discretionary accruals and a negative relation between tenure and absolute analyst forecast errors. Although it emphasized a greater reporting flexibility to reduce reported earnings and more ability of meeting earnings forecast in consistence with management, management is still able to exceed earnings forecast as a significant positive relation between tenure and signed forecast errors exists.

\section{Methodology}

A survey research design was used to gather information from the respondents concerning their opinion on the impact of mandatory audit on auditor independence in Jordan. 130 questionnaires were administered to Audit firms were returned 100, 85 of them were valued for analyzing.

\subsection{Model Specification}

For the purpose of measuring the significant relationship between the dependent variable (Auditor independency) and independent variables, an econometric model is hereby specified:

$$
A U D I N D=A O+A 1 M A R+A 2 A C R+A 3 A F+A 4 T+E T
$$

Where: $\mathrm{AO}=$ Constant;

$\mathrm{A}(\mathrm{n})=$ Parameter estimate;

MAR= Mandatory Audit Rotation;

AUDIND = Auditor Independence;

$\mathrm{ACR}=$ Auditor-Client relationship;

$\mathrm{AF}=$ Audit Fees;

$\mathrm{T}=$ Tenure;

$\mathrm{ET}=$ Stochastic error term.

4.2 Hypotheses

The relationship between the auditor and the auditee is limited to either financial; such as the payment of audit fees, or personal interactions; such as the provision of non-audit services. The American institute of certified public accountants' (AICPA) Special Committee on Assurance Services has identified several new assurance services such as risk assessment, business performance management, information systems reliability, electronic commerce, and health care performance measurement (Telborg, 1996). Auditor's main concern is to question the reasonableness of financial statement assertions made by the auditee, maintaining judicial impartiality (AICPA, 1997b). This can be highly affected by integrity and independence; which in turn is affected by many factors such as the audit lengthy tenure, which may decrease the intensity of scrutiny and the readiness to apply professional skepticism (Mautz \& Sharaf, 1961), and the far that the relationship can get before a mutuality of interests is created (Sutton, 1993).

H1: There is a significant positive relationship between auditor independency and the Auditor-Client relationship.

Many published Studies in the USA have studied the effect of audit firm tenure on audit quality (Ghosh \& Moon, 2004; Carcello \& Nagy, 2004; Myers et al., 2003; Johnson et al., 2002; Geiger \& Raghunandan, 2002). Generally they came up with a conclusion supportive of the GAO's conclusions that conclude as the tenure increases, so will the audit quality. And they show that most of the mistakes in the audit reports are most likely to happen in the first few years of the tenure of a new audit firm. However, there were a few studies that have studied and examined whether the audit partner rotation also has a negative effect on audit quality. Audit firm rotation and audit partner rotation can increase the risk of audit failures and mistakes during the first few years of the auditor tenure if the rotation makes it very difficult for the new partner to learn about the client's operations (Cameran et al., 2005).

\section{H2: There is a significant positive relationship between auditor independency and audit tenure.}

Auditor independence is the most important feature in audit profession. Lack of auditor independence may cause 
injustice, problem between the audit firm and the client and in some cases it may cause bankruptcy and business damage. When the auditor is regarded being independent, the financial information are more confidential for the public and used to make right decisions (Ghosh \& Moon, 2004; Cameran et al., 2005). There is a relation between audit fees and auditor loyalty, It shows whether the client paying less or more audit fees relative to other company, are more like to be loyal to their auditors. There is a significant effect on client degree of loyalty to their audit firms depending on relative audit fees. When there is dissatisfaction with the services provided by the auditor, the client has the right to switch auditors whenever they want. (Carcello, 2003) findings shows that high audit fees lead to high auditor dismissal, in another word lead to auditor switching. Result to weak relationship between the client and the audit firms. (Ettredge et al., 2007) results show client paying lower audit fees comparable with other companies be more likely loyal to their audit firms.

\section{H3: There is a significant negative relationship between Auditor independency and Audit fees.}

In the absence of audit rotation the auditor may using the same approach and audit program for several years, audit will lack the creativity it had in the beginning of the time that it will become predictable and ineffective (Hoyle, 1978). Audit rotation shall help to get a fresh perspective on the client's financial statements and the new audit firm might be able to detect things in statements that the previous firm couldn't overlook and errors of the previous firm (McLaren, 1958). It also gives the opportunity to scrutinize other firm's work instead of just applying the peer review program (Catanach et al., 1999). This motivates audit firms to do their best in order to avoid embarrassment knowing some experts are to judge their work and competition, and differentiate themselves through trying to attract new clients. However, there are some professionals who oppose audit rotation for many reasons.

\section{H4: There is a significant positive relationship between auditor independence and auditor rotation.}

Table 1. Summary of the regression results

\begin{tabular}{lcc}
\hline Independent variable & General models & Final models \\
\hline Constants & $1.388^{*}$ & 1.371 \\
Relationship & 0.007 & 0.007 \\
& $0.265^{* *}$ & $0.277^{* *}$ \\
Tenure & 0.07 & 0.05 \\
& 0.041 & 0.704 \\
Fees & 0.44 & 0.495 \\
& $-0.237^{* *}$ & $0.230^{* *}$ \\
Rotation & 0.05 & 0.05 \\
& $0.555^{*}$ & $0.579^{*}$ \\
\end{tabular}

Note. Model 1: $\mathrm{R}^{2}=0.308$; Adjusted $\mathrm{R}^{2}=0.263$; Model 2: $\mathrm{R}^{2}=0.307$; Adjusted $\mathrm{R}^{2}=0.273$.

*Significant at $1 \%$;** Significant at $10 \%$.

H1: There is a significant positive relationship between auditor independence and auditor-client relationship.

The regression result in Table 1 reveals a positive relationship between IND and $\mathrm{R}(\beta=.277)$. However, their relationship is statistically insignificant at the .05 level $(\rho=.05)$. Thus, H1 accepted.

$\mathrm{H} 2$ : There is a significant positive relationship between auditor independence and audit tenure.

With reference to table 5 , it is clear that T and IND are positively related $(\beta=.704)$. However, the relationship is statistically insignificant at the .05 level $(\rho=0.495)$. Thus, $\mathrm{H} 2$ cannot be accepted.

H3: There is a significant negative relationship between Audit fees and Auditor independence.

The regression result in Table 1 reveals a negative relationship between F and IND ( $\beta=-0.23)$. However, the relationship is found to be.

Statistically insignificant the .05 level $(\rho=-0.05)$. Thus, H3 accepted. 
H4: There is a significant positive relationship between mandatory rotation and Auditor independence.

According to Table 1, ROT has a significant Positive relationship with IND $(\beta=0.579)$. Furthermore, the relationship is found to be significant with $(\rho=0.002)$. Thus, H4 accepted.

\section{Conclusions}

\subsection{The Effect of the Auditor Rotation on the Auditor Independency}

There was a positive significant relationship between the auditor rotation and the auditor independency, in general when the auditor rotation increases the auditor independency increases, sometimes auditors use the same methods and the same techniques in auditing a specific firm which sometimes may lead to some misstatements and can increase the chances of firm fraud or manipulation and that is consistent with (Hoyle, 1978; McLaren, 1958) studies.

In the researchers personal point of view, encouraging firms to use the auditor rotation every set of years because auditor rotation is an essential factor which enhances the auditor independency due to the apprehension of the auditor that the next auditor or audit firm may discover some misstatements made by him, so usually the auditor will try to do his job in a perfect way, the auditor rotation may also prevent relationships between auditors and the audited firm which means that auditor rotation will play a main role in maintaining auditor independency and enhancing the audit quality.

\subsection{The Effect of the Audit Fees on the Auditor Independence}

Throughout the research, there is a negative relationship between the audit fees and the auditor independency. The researchers personal opinion if the audit fees decrease, the independence and loyalty increase because the market competition increase between the auditors, and the auditors needs to prove themselves by implement a high percentage of dependency and loyalty which leads to a high professional work and increase the credibility of financial statement with low or normal fees, and that is consistent with (Ettredge et al., 2007; Cameran et al., 2005). And the auditor independence decrease if the audit fees increase because the client may use the high fees to encourage the auditor to work properly with full professionally and loyalty, In other word the client has to pay more fees in order to acquire what he want, and the client may purchase the auditor independency when applying a high fees comparable with other clients.

\section{References}

Accounting Today. (2004). Newsbriefs: PwC settles Raytheon suit for \$50M. Accounting Today, 18(11), 3.

AICPA. (1992). SEC practice section. Statement of Position Regarding Mandatory Rotation of Audit Firms of Publicly Held Companies, American Institute of Certified Public Accountants, New York, NY.

Arel, B., Brody, R., \& Pany, K. (2005). Audit firm rotation and audit quality. The CPA Journal, January.

Basu, S. (1997). The conservatism principle and the asymmetric timeliness of earnings. Journal of Accounting and Economics, 24, 3-37. http://dx.doi.org/10.1016/S0165-4101(97)00014-1

Cameran, M., Di Vincenzo, D., \& Merlotti, E. (2005). The audit firm rotation rule: A review of the literature. Working paper, SDA Boccini School of Management, Milan.

Carcello, J. V., \& Nagy, A. L. (2004). Audit firm tenure and fraudulent financial reporting. Auditing: A Journal of Practice \& Theory, 23(2), 55-69. http://dx.doi.org/10.2308/aud.2004.23.2.55

Carcello, J., \& Neal, T. (2003). Audit committee characteristics and auditor dismissals following 'new' going-concern reports. The Accounting Review, 78(1), 95-117. http://dx.doi.org/10.2308/accr.2003.78.1.95

Carey, P., \& Simnett, R. (2006). Audit partner tenure and audit quality. The Accounting Review, 81(3), 653-676. http://dx.doi.org/10.2308/accr.2006.81.3.653

Catanach, A. H., \& Walker, P. L. (1999). The international debate over mandatory auditor rotation: A conceptual research framework. Journal of International Accounting, Auditing, \& Taxation, 8(1), 43-66. http://dx.doi.org/10.1016/S1061-9518(99)00004-X

Clements. (2011). The importance of an audit system to companies. Retrieved from http://smallbusiness.chron.com/importance-audit-system-companies-14705.html

Commission on Auditors' Responsibilities (The Cohen Commission). (1978). Report, Conclusions, and Recommendations. New York, NY: AICPA.

Elliott, R. K., \& Pallais, D. M. (1997). To market, to market we go. The Journal of Accountancy. 
Ettredge, M., Li, C., \& Scholz, S. (2007). Audit fees and auditor dismissals in the Sarbanes-Oxley era. Accounting Horizons, 21(4), 371-386. http://dx.doi.org/10.2308/acch.2007.21.4.371

European Commission. (2011). Proposal for a regulation of the European parliament and of the council on specific requirements regarding statutory audits of public-interest entities. Retrieved from http://ec.europa.eu/internal_market/auditing/docs/reform/regulation_en.pdf

Fargher, N. et al. (2008). The effect of audit partner tenure on client managers' accounting discretion. Managerial Auditing Journal, 23(2), 161-186. http://dx.doi.org/10.1108/02686900810839857

Flint, D. (1988). Philosophy and principles of auditing - An introduction. London: Macmillan Education Ltd.

Francis, J. R. (2004). What do we know about audit quality? The British Accounting Review, 36(4), 345-368. http://dx.doi.org/10.1016/j.bar.2004.09.003

GAO. (2003). Public accounting firms: Required study on the potential effects of mandatory audit firm rotation. Report to the Senate Committee on Banking, Housing, and Urban Affairs and the House Committee on Financial Services, GAO-04-216, November, United States General Accounting Office, Washington, DC.

Geiger, M., \& Raghunandan, K. (2002). Auditor tenure and audit reporting failures. Auditing: A Journal of Practice \& Theory, 21(1), 67-78. http://dx.doi.org/10.2308/aud.2002.21.1.67

Ghosh, A., \& Moon, D. (2004). Auditor tenure and perceptions of audit quality. Working paper, The Securities and Exchange Commission, Washington, DC.

Hamilton, J., Ruddock, C., Stockes, D., \& Taylor, S. (2005). Audit partner rotation, earnings quality and earnings conservatism. Retrieved from http://papers.ssrn.com/ sol3/papers.cfm?abstract_id1/4740846

Hoyle, J. (1978, May). Mandatory rotation: The arguments and an alternative. The Journal of Accountancy, 69-78.

Izedonmi, F. O. I. (2000). Introduction to auditng. Benin, Nigeria: Ambik Press Johnson V.E.

Jack, O. (2009). External auditing of financial statements: Its importance to your company and business. Business Accent, February 2009.

Johnson, V., Khurana, I., \& Reynolds, K. (2002). Audit-firm tenure and the quality of financial reports. Contemporary Accounting Research, 19(4), 638-60. http://dx.doi.org/10.1506/LLTH-JXQV-8CEW-8MXD

Kahn, J. (2002, January 7). One plus one makes what? Fortune, 145(1), 88-90.

Khatab, G. (2013). The effect of joint audit and audit rotations of the firm's value.

Levitt, A. (2000). Renewing the covenant with investors. Speech delivered at the NYU Center for Law and Business, New York, May 10. Retrieved from http://www.sec.gov/news/speech/spch370.htm

Levitt, A. (2002). Opening statement. Speech delivered at the Committee on Governmental Affairs of United States Senate, Washington DC, January 24.

Mautz, R., \& Sharaf, H. (1961). The philosophy of auditing. Sarasota, FL: American Accounting Association.

McLaren, N. L. (1958, July). Rotation of Auditors. The Journal of Accountancy, 106, 41-44.

Myers, J., Myers, L., \& Omer, T. (2003). Exploring the term of the auditor-client relationship and the quality of earnings: A case for mandatory auditor rotation? The Accounting Review, 78(3), 779-99. http://dx.doi.org/10.2308/accr.2003.78.3.779

Porter, B., Simon, J., \& Hatherly, D. (2003). Principles of External Auditing. Chichester: Wiley.

Ramos, M. (2002, Dec.). SAS 99 gives CPAs new chance to reclaim reputation. Retrieved from http://www.cpa2biz.com/News/Viewpoint/SAS+99+Gives+CPAs+New+Chance+to+Reclaim+Reputation.h tm

Simunic, D. (1984). Auditing, consulting, and auditor independence. Journal of Accounting Research, 22(2), 679-702. http://dx.doi.org/10.2307/2490671

Sutton, S. G. (1993). Towards an understanding of the factors affecting the quality of the audit process. Decision Sciences, 24(1), 88-105. http://dx.doi.org/10.1111/j.1540-5915.1993.tb00464.x

Telborg, R. (1996). CPA leaders forge new vision: New paradigm scarps traditional view of firm, regulation. Accounting Today, Nov. 25-Dec. 15, pp. 1, 38-39, 44, 47-48.

Vanstraelen, A. (2000). Impact of renewable long-term audit mandates on audit quality. The European Accounting Review, 9(3), 419-442. http://dx.doi.org/10.1080/09638180020017140 


\section{Copyrights}

Copyright for this article is retained by the author(s), with first publication rights granted to the journal.

This is an open-access article distributed under the terms and conditions of the Creative Commons Attribution license (http://creativecommons.org/licenses/by/3.0/). 